\title{
Exit, Voice and Loyalty from the Perspective of Hedge Funds Activism in Corporate Governance
}

\author{
Alessio M. Pacces*
}

\begin{abstract}
This article discusses hedge funds activism based on Hirschman's classic. It is argued that hedge funds do not create the loyalty concerns underlying the usual short-termism critique of their activism, because the arbiters of such activism are typically indexed funds, which cannot choose short-term exit. Nevertheless, the voice activated by hedge funds can be excessive for a particular company. Furthermore, this article claims that the short-termism debate cannot shed light on the desirability of hedge funds activism. Neither theory nor empirical evidence can tell whether hedge funds activism leads to short-termism or long-termism. The real issue with activism is a conflict of entrepreneurship, namely a conflict between the opposing views of the activists and the incumbent management regarding in how long an individual company should be profitable. Leaving the choice between these views to institutional investors is not efficient for every company at every point in time. Consequently, this article argues that regulation should enable individual companies to choose whether to curb hedge funds activism depending on what is efficient for them. The recent European experience reveals that loyalty shares enable such choice, even in the midstream, operating as dual-class shares in disguise. However, loyalty shares can often be introduced without institutional investors' consent. This outcome could be improved by allowing dual-class recapitalisations, instead of loyalty shares, but only with a majority of minority vote. This solution would screen for the companies for which temporarily curbing activism is efficient, and induce these companies to negotiate sunset clauses with institutional investors.
\end{abstract}

Keywords: Uncertainty, entrepreneurship, agency costs, loyalty shares, institutional investors

* Professor of Law \& Finance, Erasmus School of Law, and Research Associate, European Corporate Governance Institute. I wish to thank Patrick Bolton, Bart Bootsma, Luca Enriques, Jill Fisch, Jesse Fried, Ron Gilson, Jeff Gordon, Zohar Goshen, Joe McCahery, Darius Palia, Arkadiusz Radwan, Eric Talley, two anonymous referees and participants in the European Forum on Securities Regulation (EFSR) at Bucerius Law School in Hamburg and in the Blue Sky lunch seminar at Columbia Law School for helpful comments on a previous version of this article. Editorial assistance by the staff of the Erasmus Law Review is gratefully acknowledged. Usual disclaimers apply.

\section{Introduction}

Shareholder activism in publicly held companies is much in the news, particularly hedge funds activism. ${ }^{1}$ Activist hedge funds engage the management of an underperforming listed company in which they have bought a significant stake. Hedge funds seek to determine a change in the governance or in the strategy, from which they will profit by selling their shares at a premium after performance has returned to full potential.

Last year, the U.S. hedge fund Value Act Capital became the largest shareholder of the UK engineering company Rolls Royce, seeking to persuade the management to restructure the company. ${ }^{2}$ Engagements by activist hedge funds have included pharmaceutical U.S. companies such as DuPont and Allergan. ${ }^{3}$ Hedge funds activism has not spared giant corporations, such as Microsoft and Apple. The phenomenon is not limited to U.S. or UK companies. Activists have targeted several companies in continental Europe, such as the Swedish automotive company Volvo, the German steel company ThyssenKrupp, the Dutch bank ABN-AMRO, the French media company Vivendi and the largest Italian telecom operator, Telecom Italia. ${ }^{4}$ Activism appears to

1. Shareholder activism can be identified as actions by a shareholder or a group thereof aimed at bringing about change in a public company without trying to gain control. See S. Gillan and L.T. Starks, 'The Evolution of Shareholder Activism in the United States', 19 Journal of Applied Corporate Finance 55 (2007). Only a small subset of hedge funds pursue activism. Activist hedge funds engage target companies with a peculiar strategy, described below in the text. This is called 'entrepreneurial activism', to distinguish it from more traditional forms of shareholder activism. See A. Klein and E. Zur, 'Entrepreneurial Shareholder Activism: Hedge Funds and Other Private Investors', 64 Journal of Finance 187 (2009). Also see infra, text to notes 35-40.

2. See 'Rolls-Royce Gets Activist Fund Value Act as Biggest Investor', Bloomberg Business (31 July 2015). available at: <http://bloom.bg/ 1Qjgm0Q> (last visited 17 June 2016). More recently, Rolls Royce agreed to reserve a board seat for Value Act conditional on a Value Act promising to keep ownership within a certain range and not seek the break-up of the company. See 'Rolls-Royce Agrees Value Act Board Deal', Financial Times, 2 March 2016, available at: <http://on.ft.com/ 1oXZXpu> (last visited 17 June 2016).

3. See J.C. Coffee, Jr., 'Lessons of DuPont: Corporate Governance for Dummies', CLS Blue Sky Blog (2015), available at: <http://clsbluesky. law.columbia.edu/2015/06/01/the-lessons-of-dupont-corporategovernance-for-dummies/> (last visited 17 June 2016).

4. See The New Barbarians - Shareholder Activists Have Europe in Their Sights, in Skadden's 2014 Insights - Global M\&A, available at: <www. skadden.com/insights/new-barbarians-shareholder-activists-haveeurope-their-sights> (last visited 17 June 2016). 
have an impact also in concentrated ownership structures, where one or more dominant shareholders are in control. ${ }^{5}$ Even in dispersed ownership structures, hedge funds activists do not always manage to obtain from management all they want. ${ }^{6}$ Because hedge fund activists have become one of the most powerful influencers of corporate governance worldwide, they have attracted significant attention from policymakers who, in most cases, are concerned with how to curb such power.

This article aims to discuss the policy response to hedge funds activism from a law and economics perspective. The analysis is based on a seminal study of feedback mechanisms in large organisations, ranging from governments to corporations: Albert Hirschman's book, Exit, Voice and Loyalty. ${ }^{7}$ The problem Hirschman tried to address in his 1970 book is rather similar to activist hedge funds' concern: How to bring a company's performance back to full potential. Hirschman's theory can help frame the question whether and under what conditions activism is desirable, which in turn can inform policymaking in this field.

In Hirschman's terms, activism is the quintessence of voice. Voice of shareholders serves the important function of alerting the management about the decline of a specific company. ${ }^{8}$ Voice is alternative to exit. Exit of shareholders also alerts the management about a company's decline, but more indirectly, through the price mechanism. ${ }^{9}$ As a result, exit may postpone the realisation of decline until it is too late to do something about it. Takeovers are a good illustration of how the exit mechanism impacts corporate governance. Because takeovers are expensive, they operate as a feedback mechanism only in cases of severe underperformance. ${ }^{10}$ One important aspect of Hirschman's framework is loyalty. ${ }^{11}$ The ability of shareholders to exit through liquid stock markets normally disincentivises them from exercising voice. This is not the case if there is loyalty to a given company. Making exit more expensive, loyalty commits shareholders to voice. Loyalty has become very popular in today's policy debate, but not quite in the

5. See e.g. T. Poulsen, T. Strand \& S. Thomsen, 'Voting Power and Shareholder Activism: A Study of Swedish Shareholder Meeting', 18 Corporate Governance: An International Review 329 (2010) on Sweden; W. Bessler, W. Drobetz \& J. Holler, 'The Returns to Hedge Fund Activism in Germany', 21 European Financial Management 106 (2013) on Germany; and M. Belcredi and L. Enriques, 'Institutional Investor Activism in a Context of Concentrated Ownership and High Private Benefits of Control: The Case of Italy', in J.G. Hill and R.S. Thomas (eds.), Research Handbook on Shareholder Power (2015) 383.

6. See M. Becht et al., 'The Returns to Hedge Fund Activism: An International Study', European Corporate Governance Institute, Finance Working Paper No. 402/2014 (2016), (revision 27 May 2016), reporting an average $53 \%$ success rate on a global level $(61 \%$ in the USA; $50 \%$ in Europe; $21 \%$ in Asia). Success is defined as achievement of at least one of the outcomes sought for in the campaign.

7. A.O. Hirschman, Exit, Voice, and Loyalty: Responses to Decline in Firms, Organizations, and States (1970).

8. Ibid., at 30 .

9. Ibid., at 22-24.

10. P. Bolton, M. Becht \& A. Röell, 'Corporate Law and Governance', in A.M. Polinsky and S. Shavell (eds.), Handbook of Law and Economics (2007), at 879-880.

11. Hirschman, above n. 7, at 77-19. same sense as Hirschman's. While to Hirschman loyalty meant a commitment device for shareholders to use voice instead of exiting an organisation they are dissatisfied with, for policymakers, loyalty distinguishes 'good' voice from 'bad' voice in corporate governance - hedge funds activism being an illustration of the latter. ${ }^{12}$

At first sight, concerns with shareholder voice are puzzling. Vocal shareholders, such as activist hedge funds, are doing other investors a favour. In dispersed ownership structures, hedge funds foster managerial accountability to investors, particularly when managers perform poorly. Similarly, in concentrated ownership structures, hedge funds are guarding minority shareholders against outright expropriation. In sum, the very presence of hedge funds activism reduces the average cost of capital for companies, by way of improving investor protection. ${ }^{13}$ The issue with hedge funds, however, is subtler. Hedge funds are blamed for injecting short-termism in corporate governance. Short-termism is a popular way to characterise stock market imperfection: Stock markets overweigh the short-term income of a company at the expense of its long-term profitability. ${ }^{14}$ If financial markets were informationally efficient, there could be no conflict between short-term and long-term value maximisation. Although whether and to what extent stock markets are informationally efficient remains controversial, this article assumes that there may be indeed a conflict between the short term and the long term. Particularly, the stock market price may fail to incorporate future profit opportunities that are far into the future and highly uncertain. Still, this limitation of stock market prices tells us nothing about the desirability of hedge fund activism. The real question is whether, given the possibility that stock markets are short-termist, hedge

12. Policymakers on both sides of the Atlantic have taken initiatives to promote long-term, loyal shareholding. Invariably, these initiatives consist in creating a disparity (in terms of voting power, cash flow rights or taxes) between long-term and short-term shareholders. See Aspen Institute, 'Overcoming Short-Termism: A Call for a More Responsible Approach to Investment and Business Management' (2009), available at: <www.aspeninstitute.org/sites/default/files/content/docs/pubs/ overcome_short_state0909_0.pdf> (last visited 17 June 2016); J. Kay, 'The Kay Review of UK Equity Markets and Long-Term Decision Making (Final Report)' (July 2012), available at: <www.bis.gov.uk/assets/ biscore/business-law/docs/k/12-631-kay-review-of-equity-marketsinterim-report> (last visited 17 June 2016); 'Brussels Aims to Reward Investor Loyalty', Financial Times (23 January 2013), available at: <http://on.ft.com/WWciED> (last visited 17 June 2016); Report by the EU Parliament Committee on Legal Affairs on the proposal for a Directive of the European Parliament and of the Council amending Directive 2007/36/EC as regards the encouragement of long-term shareholder engagement and Directive 2013/34/EU as regards certain elements of the corporate governance statement (12 May 2015), available at: $<$ www.europarl.europa.eu/sides/getDoc.do?type=REPORT \&mode $=$ $\mathrm{XML}$ \&reference $=\mathrm{A} 8-2015-0158$ \&language $=E N>$ (last visited 17 June 2016) (hereinafter Cofferati Report 2015).

13. R. La Porta et al., 'Legal Determinants of External Finance', 52 Journal of Finance 1131 (1997).

14. See C.A. Hill and B. McDonnel, 'Short and Long Term Investors (and Other Stakeholders Too): Must (and Do) Their Interests Conflict?', in C.A. Hill and S.D. Solomon (eds.), Research Handbook on Mergers and Acquisitions (2016) [forthcoming], available at: <http://ssrn.com/ abstract=2699324> (last visited 17 June 2016) for an informal illustration. 
funds activism undermines corporate governance by steering managers towards value-destroying choices. ${ }^{15}$

The scepticism of policymakers towards hedge funds activism is based on the assumption that short-termism is unambiguously value-destroying. Because hedge funds are guided by the stock market, where they realise the gains from activism, hedge funds must be shorttermist too and induce management to sacrifice longterm shareholder value for short-term performance. Long term-shareholding could overcome this problem. So long as long-term shareholders face high costs of exit, they are to be considered loyal in Hirschman's sense. In exercising voice, long-term shareholders should have the incentives to care for the company's well-being in the long run. Although hedge funds are key to activate the voice of long-term investors, ${ }^{16}$ several policy measures have been proposed to curb hedge funds activism aiming to encourage long-term shareholdings instead. A group of these proposals aim to reduce the impact of hedge funds through disclosure obligations, which would undermine hedge funds' business model while being neutral to longer-term shareholdings. ${ }^{17}$ Another group of proposals aim at tilting the balance of powers towards more loyal shareholders, or at offering them financial incentives, by way of so-called loyalty shares. ${ }^{18}$

Albeit popular among policymakers, the short-termism argument is regarded with scepticism by a majority of commentators, who, accordingly, oppose the curbs of hedge funds activism and the favour towards loyal shareholders. ${ }^{19}$ This is because the empirical evidence does not support the more radical formulation of the short-termism claim, namely that activism induces managers to go for the 'quick buck' and destroy long-term shareholder value. ${ }^{20}$ On average, hedge funds activism brings about a substantial short-term increase in shareholder value, which is not reversed in the aftermath of the engagement. Although the empirical evidence also supports the view that managers occasionally engage in long-term value destruction to cater to short-term

15. M.J. Roe, 'Corporate Short-Termism - in the Boardroom and in the Courtroom', 68 Business Lawyer 977 (2013), at 985.

16. See R.J. Gilson and J.N. Gordon, 'The Agency Costs of Agency Capitalism: Activist Investors and Revaluation of Governance Rights', 113 Columbia Law Review 863 (2013). One interesting implication of this point is that, however short-termist hedge funds are, short-termism would not occur in corporate governance if investors with a long-term horizon were always decisive on an activist's campaign. As we will see infra, text to notes $116-118$, the reality is more nuanced than this.

17. See A.O. Emmerich et al., 'Fair Markets and Fair Disclosure: Some Thoughts on the Law and Economics of Blockholder Disclosure, and the Use and Abuse of Shareholder Power', 3 Harvard Business Law Review 135 (2013).

18. See J. Fox and J.W. Lorsch, 'What Good Are Shareholders?' 90 Harvard Business Review 48 (2012); P. Bolton and F. Samama, 'Loyalty-Shares: Rewarding Long-term Investors', 25 Journal of Applied Corporate Finance 86 (2013); Cofferati Report (2015), above n. 12.

19. L.A. Bebchuk, A. Brav \& W. Jiang, 'The Long Term Effects of Hedge Fund Activism', 113 Columbia Law Review 1637 (2015).

20. See infra text to notes 71-75. investors' sentiment, ${ }^{21}$ hedge funds activism seems not to be directly responsible for this. What the empirical evidence does not and cannot tell us, however, is whether the presence of hedge funds activism is desirable for corporate governance in general.

In this article, I will argue that the short-termism debate does not shed much light on this crucial question. I will discuss several reasons. For one, short-term and longterm horizons are ill-defined. Any action can be characterised as short-term depending on the definition of the long term. This is not very helpful for policy purposes. Second, even if we identified a conventional definition of short term as opposed to the long term, which horizon is preferable for the purpose of managing a company would not be obvious. ${ }^{22}$ What is the 'right term' to create value is a difficult question that may be impossible to answer with precision. Efficiency may require managing for the short term, for instance because, according to Hirschman's framework, in highly competitive markets feedback must be immediate in order to allow for timely 'recuperation' from underperformance. In this case, the problem may rather be long-termism than short-termism. ${ }^{23}$ However, Hirschman was very clear that what is an efficient recuperation mechanism for a firm may be inefficient for another, and this circumstance is susceptible to change over time. ${ }^{24}$ Therefore, efficiency may require as well managing for the long term, at least to the extent that the definition of long term allows for feedback to intervene timely. In this case, concerns for short-termism may be warranted. The conflict between the short-term and the long-term view of profit maximisation varies with context and, as such, is impossible to resolve empirically. Even if one could identify the 'right term' with precision, that would vary with the individual company and over time. Because companies are not alike and are dynamic, the positive stock returns associated with the shortening of horizons commanded by hedge fund activism says nothing about the efficiency of the engagement. To claim that activism is value-enhancing one would need to compare the target's performance not with a market index, as in a typical event study, but rather with a counterfactual, similar firm that has not capitulated to activism and is insensitive to its threat. ${ }^{25}$ The feasibility

21. B.J. Bushee, 'The Influence of Institutional Investors on Myopic R\&D Investment Behavior', 73 Accounting Review 19 (1998); and B.J. Bushee, 'Do Institutional Investors Prefer Near-Term Earnings over Long-Run Value', 18 Contemporary Accounting Research 207 (2001).

22. See an extensive discussion of this point in J.M. Fried, 'The Uneasy Case for Favoring Long-Term Shareholders', Yale Law Journal 1554 (2014).

23. For empirical evidence that firms more exposed to competition benefit from the influence of short-term investors, See M. Giannetti and X. Yu, 'The Corporate Finance Benefits of Short Horizon Investors', European Corporate Governance Institute (ECGI) - Finance Working Paper No. $467 / 2016$ (2016), available at <http://ssrn.com/abstract=2723357> (last visited 21 June 2016).

24. Hirschman, above n. 7, at 124

25. See V.A. Atanasov and B.S. Black, 'Shock-Based Causal Inference in Corporate Finance Research', ECGl-Finance Working Paper No. 448 (2015), available at <http://ssrn.com/abstract=1718555> (last visited 21 June 2016); J.D. Angrist and J-F. Pischke, Mostly Harmless Econometrics: An Empiricist's Companion (2012). 
of such research design is complicated by the fact that companies that are not engaged, but could be, react in anticipation of engagement and thus are not good as counterfactual. ${ }^{26}$ Although recent studies of activism have made significant progress in coping with these causality issues, ${ }^{27}$ the fact remains that firms that are (or can be) targeted by activism are radically different from those that are not (and cannot be). Consequently, the activists' views on, for instance, innovation cannot be compared with those of companies that are not susceptible to targeting by hedge funds. Most likely, their different performance over the same horizon - whether long or short - will be a reflection of the different kinds of innovation they engage in.

The debate on the right horizon for managing a listed company confounds the effect - short-termism - with the cause - uncertainty. Building on a long-standing tradition of students of uncertainty, ${ }^{28}$ this article claims that the choice of the horizon to maximise profits belongs to the entrepreneur because he or she is the one to make choices under uncertainty. Consequently, this article claims that the problem of hedge fund activism is to be framed as a conflict of entrepreneurship between the activist and the incumbent management. In corporate governance, entrepreneurship is a bet on forthcoming change, which will be profitable if the change happens as predicted and unprofitable otherwise. ${ }^{29}$ The size of the bet shows the entrepreneur's commitment to the project. This, in turn, affects the funds that can be raised from outside investors. ${ }^{30}$ Investors are not anticipating the change the entrepreneur is betting on, which is a precondition for the change to be profitable if it occurs. Investors leave corporate control with the management so long as they trust them to be good entrepre-

26. M. Barzuza and E.L. Talley, 'Short-Termism and Long-Termism', Columbia Law and Economics Working Paper No. 526 (2016), argue, in a game-theoretic fashion, that a substantial part of managerial shorttermism may occur 'off the equilibrium path', namely under the rational expectation of engagement by hedge funds. The effect of the threat of engagement is hard to capture empirically.

27. See e.g. A. Brav et al., 'Shareholder Power and Corporate Innovation: Evidence from Hedge Fund Activism', Kelley School of Business Research Paper 2014-05 (2014), analysing the impact of hedge funds activism on innovation with propensity score matching, and finding that while activism reduces innovation input, it does not diminish innovation output. See also K.J.M. Cremers et al., 'Hedge Fund Activism and LongTerm Firm Value' (2016), available at <http://ssrn.com/abstract= 2693231 > (last visited 21 June 2016). Based on a matched sample of companies not engaged by hedge funds, they find that companies that are engaged forego some long-term value creation. However, see infra, note 78 and accompanying text.

28. Uncertainty has been studied extensively by J.M. Keynes, The General Theory of Employment, Interest and Money (1936), (reprinted BN Publishing 2008), and F.H. Knight, Risk, Uncertainty and Profit (1921). According to Knight's influential distinction, uncertainty differs from risk because it cannot be assigned a probability; entrepreneurs typically make choice under uncertainty as opposed to the risky choices of other market players. Similarly, Keynes attributes to uncertainty a prominent role in forming long-term expectations, particularly of the entrepreneur as opposed to financiers. For both Keynes and Knight, entrepreneurship is the response to unquantifiable uncertainty.

29. A.M. Pacces, Rethinking Corporate Governance: The Law and Economics of Control Powers (2012), at 71-74.

30. A.M. Pacces, 'Control Matters: Law and Economics of Private Benefits of Control', ECGI-Law Working Paper Series No. 131 (2009). neurs. When this is no longer the case, investors would rather hand control over to another entrepreneur, by exiting and letting somebody else take over or by directly raising their voice and voting for a new management. From this perspective, hedge funds activism is a form of entrepreneurship, comparable to hostile takeovers. ${ }^{31}$ Hedge funds aim to change the strategy, the management or the governance of a target company and profit from the unanticipated market gains from such changes. In so doing, hedge funds get in conflict with the managers or the dominant shareholders who control the target company. These people may oppose the activist's demands because they are entrepreneurs too and genuinely believe they have a superior view about the company's strategy. However, they may also resist activism because they derive private benefits from running the company below its potential. Whether the incumbent management's opposition to activism stems from vision or extraction of private benefits of control, let alone whether the management is right or wrong, is hard to say when the conflict occurs. However, the conflict is not really about whether a company should be managed for the short term or the long term. It is rather a conflict between two views of entrepreneurship, namely about how the company should look like in the future, including the scenario in which managers benefit from running it inefficiently. The real policy issue is which view should prevail and whether the law should do anything to help companies to make the right choice.

Extending the approach developed by Professors Enriques, Gilson and myself for takeover regulation, ${ }^{32}$ this article argues that individual companies should decide 'who decides' when there is a conflict of views between an activist investor and the incumbent management or controlling shareholder. In the remainder of this article, I will articulate this claim as follows. In Section 2, I will start by reviewing theory and empirical evidence about hedge funds activism. As illustrated by Professors Gilson and Gordon, ${ }^{33}$ support by the institutional owners is the key to activism's success. In view of this insight, the question is whether the loyal owners - namely the investors that cannot exit strategically - can be trusted to screen hedge funds activism. While optimising individual companies' exposure to exit and voice remains crucial for efficiency, the desirability of loyalty is today more nuanced than in the world of dispersed individual owners Hirschman was living in. The real issue about shareholder activism is not whether it is long-term or short-term, but whether a company should commit to insiders' or outsiders' entrepreneurship. In Section 4, I will argue that none of the main regulatory proposals to

31. Klein and Zur, above n. 1, at 187. Note, however, the difference between activist hedge funds, which aim to change the company's operation without taking over control, and hostile bidders, which, in contrast, seek immediately to purchase control. See H.G. Manne, 'Mergers and the Market for Corporate Control', 73 Journal of Political Economy 110 (1965).

32. L. Enriques, R.J. Gilson \& A.M. Pacces, 'The Case for an Unbiased Takeover Law (with an Application to the European Union)', 4 Harvard Business Law Review 85 (2014).

33. Gilson and Gordon, above n. 16. 
screen for efficient shareholder activism - enhanced disclosure obligations and the so-called loyalty shares help companies to make that choice. On the contrary, a 'sticky' one-share-one-vote (1S1V) default ${ }^{34}$ would enable individual companies to select the efficient regime and to alter it when it becomes inefficient down the road. Section 5 concludes.

\section{Entrepreneurial Shareholder Activism}

Shareholder activism is not new. Activists have always been prompting corporate managers to act on some issue, even unrelated to the conduct of the company's business. Particularly in the United States, activists have been able to add items on the agenda of the general meeting at the company's expense, by filing a so-called shareholder proposal. ${ }^{35}$ However, such traditional activism has not been very effective, and before the advent of hedge funds activism, investors seemed unable to achieve concrete outcomes through this channel. ${ }^{36}$ Despite the regulatory differences, a similar conclusion could be made about comparable channels for traditional activism in Europe. ${ }^{37}$

Hedge funds activism is different. ${ }^{38}$ It does not simply aim to alert management on some issue by triggering a shareholder vote on it. It aims to achieve a change in the way the company is managed. Such change can be although not necessarily is - quite radical, such as the departure of the CEO or some other executives, if not the restructuring of the company. Likewise, activist hedge funds may seek to stop a change wanted by the management, for instance an acquisition. For this reason, hedge funds activism is called 'entrepreneurial activism.' This is how I will refer to it in the remainder of the article. Differently from traditional activism, the mark of entrepreneurial activism's success is not so much the level of shareholder support at the general meeting, but whether the desired change(s) happens or not. ${ }^{39}$ The business model of activist hedge funds

34. For a "Theory of Sticky Defaults" (subsequently renamed "Theory of Altering Rules"), see I. Ayres, 'Regulating Opt-Out: An Economic Theory of Altering Rules', 121 Yale Law Journal 2032 (2011).

35. Gillan and Starks, above n. 1, at 55

36. See D. Yermack, 'Shareholder Voting and Corporate Governance', 2 Annual Review of Financial Economics 103 (2010). The situation has changed more recently, though, particularly in the United States with regard to the removal of staggered boards. See J.C. Coates IV, 'Thirty Years of Evolution in the Roles of Institutional Investors in Corporate Governance', in J.G. Hill and R.S. Thomas (eds.), Research Handbook on Shareholder Power 76 (2015)

37. See e.g. A. de Jong, G.M.H. Mertens \& P.G.J. Roosenboom, 'Shareholders' Voting at General meetings: Evidence from the Netherlands', 10 Journal of Management \& Governance 353 (2006).

38. See F. Partnoy, 'U.S. Hedge Fund Activism', in J.G. Hill and R.S. Thomas (eds.), Research Handbook on Shareholder Power 99 (2015), and earlier, J. Macey, Corporate Governance: Promises Kept, Promises Broken (2008), at 244-51, for an illustration of the difference between hedge funds activism and traditional forms of shareholder activism.

39. Becht et al., above n. 6 . explains why this is so. Differently from other institutional investors, hedge funds managers charge a performance fee in addition to a percentage of the asset under management. ${ }^{40}$ This aligns their incentives with investors having a relatively high appetite for risk. Hedge funds profit from investing in stock that they can buy, hold and resell at a higher price. The purpose of entrepreneurial activists' engagement with the management of the target company is to achieve meanwhile a change that will boost the stock price.

Two factors are key for the success of entrepreneurial activism. First, the hedge fund needs to be able to buy the bulk of its stake in the company while the stock market does not anticipate the engagement. The moment the engagement is revealed, investors will anticipate gains and, discounting those for the probability that the engagement fails, the stock price will rise. Second, the activist needs to be able to persuade the management to implement the desired changes. To increase its leverage with the management, the activist can use several techniques, ranging from news campaigns to threatening a lawsuit, but the last resort is to wage a proxy context. Reached that point, the success of the engagement will depend on whether the activist has managed to attract sufficient support from other shareholders to get a favourable vote.

The support by institutional investors is crucial for successful engagement. The typical hedge fund stake in the target company is substantial, but not nearly a controlling one. ${ }^{41}$ As a result, activists must persuade institutional investors to vote for them. By the same token, engagement may succeed based on the sheer threat of winning a contested vote. ${ }^{42}$ The likelihood of winning the battle can be estimated while the investing public is still in the dark about the engagement. From the moment the hedge funds formulate their demands to the management, both parties start to speak with the largest institutional investors. Management will give in to the activists' demands when it is clear they are going to lose the vote, whereas hedge funds will withdraw from engagement when they realise that not enough institutional investors will vote for them. Most of the time the parties will settle somewhere in the middle. The fight becomes public only when no agreement can be reached. Consequently, a substantial portion of hedge funds engagement takes place behind closed doors, which, as I will explain shortly, has important consequences for empirical analyses.

As explained by Professors Gilson and Gordon, the tremendous influence activists have gained in corporate governance lately depends mainly on the re-concentra-

40. Gilson and Gordon, above n. 16.

41. For their global sample, Becht et al., above n. 6, report an average stake of $11 \%$. For the United States, other studies (Gilson and Gordon, above n. 16, at 899); N. Gantchev, 'The Costs of Shareholder Activism: Evidence from a Sequential Decision Model', 107 Journal of Financial Economics 610 (2013), at 621, report that activist investors hold $8 \%$ on average.

42. M. Becht et al., 'Hedge Fund Activism in Europe: Does Privacy Matter?', in J.G. Hill and R.S. Thomas (eds.), Research Handbook on Shareholder Power 116 (2015). 
tion of ownership that has occurred in the past few decades. $^{43}$ In the world Hirschman was living in, voice by activists was not very promising because the dispersed individual stockholders of a Berle-Means Corporation would not bother to vote, particularly against the management of the company they decided to invest in. ${ }^{44}$ However, even in the United States, the Berle-Means Corporation does no longer exist. Gilson and Gordon report that, in 2009, institutional investors held on average $73 \%$ of the equity of the thousand largest U.S. corporations. ${ }^{45}$ Unsurprisingly, the voting power of institutional investors is also quite concentrated: the representatives of institutions jointly holding control of a typical U.S. company would fit around a boardroom table. ${ }^{46} \mathrm{~A}$ recent study by the OECD provides similar results for the United Kingdom. ${ }^{47}$ Moreover, concentration of non-controlling ownership is a documented phenomenon also in countries where dominant shareholders are frequent, such as Sweden and the Netherlands. ${ }^{48}$

If roughly two dozen institutional investors hold enough votes in the typical management-controlled company to be decisive, and a substantial portion of the voting rights also in companies with dominant shareholders, one would expect institutional investors, rather than hedge funds activists, to exercise voice. The reason why this has not happened is agency costs. ${ }^{49}$ Institutional investors manage other people's money and do so with a business model that disincentivises monitoring of individual companies. Although institutional investors are very different from each other, for reasons of law, profiling and investment culture, they all hold a diversified portfolio of stock. Institutional investors charge flat fees based on assets under management, and the latter mainly depends on the institution's ability to attract funds from the competitors - that is, relative performance. Relative performance is unaffected by improving the returns of a particular portfolio company, because the competitors will free ride on that, while it is adversely affected by the cost of becoming informed about underperforming companies to engage with. Therefore, institutional investors are 'rationally reticent' ${ }^{50}$ They are not proactive in influencing corporate management, but they are responsive to other, entrepreneurial, actors who bring the case for engagement to their attention.

According to Gilson and Gordon, the activists' teaming up with institutional investors is beneficial for corporate governance. On the one hand, activists lower the agency costs of institutional ownership. On the other hand,

43. Gilson and Gordon, above n. 16, at 874 .

44. Hirschman, above n. 7, at 46.

45. Gilson and Gordon, above n. 16, at 874.

46. Ibid., at 875.

47. M. Isaksson and S. Celik, 'Who Cares: Corporate Governance in Today's Equity Markets', 8 OECD Corporate Governance Working Papers (2013).

48. P. Lekvall (ed.), The Nordic Corporate Governance Model (Stockholm: SNS Forlag 2015) and A. de Jong et al., 'Changing National Business Systems: Corporate Governance and Financing in the Netherlands, 1945-2005', 84 Business History Review 773 (2010).

49. Gilson and Gordon, above n. 16, at 889-95.

50. Ibid., at 895 . institutional investors screen activists' proposals and likely sanction only those that increase shareholder value. Empirical evidence supports the conclusion that activists give other shareholders what they want. Several studies document the association of shareholder activism with an average increase in shareholder value. ${ }^{51}$ Importantly, this increase stems from the activists' achieving outcomes of sort, namely garnering broad support from institutional investors. Moreover, the increase is larger for outcomes more related to strategic change than for others. ${ }^{52}$

Reducing agency costs undoubtedly improves the efficiency of corporate governance, which in this article is defined as maximisation of shareholder value. ${ }^{53}$ However, this approach does not demonstrate that hedge fund activism is always value-increasing. Several objections, concerning the effectiveness of the screening by institutional investors and the short-termism of the activists' demands, have been raised. ${ }^{54}$ In the remainder of this section, I will show that while the first set of objections appears to be overstated, the second claim has some merit, albeit in a different way than normally understood. Particularly, the empirical evidence can only reject the most trivial version of the short-termism claim, namely that the stock market gains brought about by the activist's engagement are subsequently reversed. However, empirical analyses cannot answer the more fundamental question of whether hedge funds activism increases (or decreases) value across the board.

It is sometimes argued that institutional investors do not really exercise judgment, but rather blindly follow the recommendations of proxy advisors, notably including global market leaders such as Institutional Shareholders Services (ISS) and Glass-Lewis. ${ }^{55}$ The argument echoes

51. Klein and Zur, above n. 1; A. Brav, J. Wei, F. Partnoy \& R. Thomas, 'Hedge Fund Activism, Corporate Governance, and Firm Performance', 63 Journal of Finance 1729 (2008); C.P. Clifford, 'Value Creation or Destruction? Hedge Funds as Shareholder Activists', 14 Journal of Corporate Finance 323 (2008).

52. Becht et al., above n. 6 .

53. There are two reasons to choose shareholder value as a welfare criterion for the purposes of this article. First, this article deals with shareholder feedback in corporate governance. Although Hirschman's framework applies to feedback from other stakeholders, hedge funds activism and the institutional investors' support that makes it viable are undoubtedly shareholders' reactions to a firm's governance. Second, this article contends that corporate governance is not directly responsible for the externalities generated by corporate enterprises (with the exception of entrepreneurship). See infra, text to notes 121-122. Therefore, the judgment on the desirability of hedge funds activism is independent of the effects on stakeholders different from shareholders. This approach allows using a simple Kaldor-Hicks test to determine whether hedge funds activism is efficient - namely whether shareholders are net better off. This is in line with mainstream finance literature on the impact of hedge funds activism. For a similar approach, albeit applied to takeovers, see Enriques and others, above n. 32, at 85.

54. See especially J.C. Coffee, Jr. and D. Palia, 'The Wolf at the Door: The Impact of Hedge Fund Activism on Corporate Governance', 1 Annals of Corporate Governance 1 (2016). But sceptics include, among others, Bolton and Samama, above n. 18, and M. Lipton, Important Questions about Activist Hedge Funds, available at: <http://corpgov.law.harvard. edu/2013/03/09/important-questions-about-activist-hedge-funds/> (last visited 21 June 2016).

55. Coffee and Palia, above n. 54 
policymakers' scepticism about proxy advisors. ${ }^{56}$ It has a theoretical basis. Because the institutional investors' business model does not encourage monitoring individual companies, institutions used to be passive about voting. Recently, however, particularly U.S. legislation has compelled major categories of investors - mutual funds and pension funds - to disclose their voting policies. ${ }^{57}$ Hence, to avoid embarrassment, institutional investors purchase professional advice from proxy advisors and, arguably, mechanically follow their advice. Because the quality of this advice is questionable, ${ }^{58}$ institutional investors that follow it cannot be trusted to screen hedge funds activism effectively. However, the influence of proxy advisors on institutional investors may be overstated.

Virtually all mutual funds, which are the largest U.S. corporate owners taken together, subscribe to one or more proxy advisors, including ISS. However, only $25 \%$ of mutual funds always vote in line with the proxy advice, and, on an asset-weighted basis, reliance on management's advice is higher than reliance on ISS. ${ }^{59}$ Reliance varies greatly among institutional investors because they differ considerably too, especially in their size, investment strategies and horizons. Not only do the largest U.S. asset managers, which have the largest dollar-value stakes, vote independently from $\mathrm{ISS}^{60}$; in some circumstances they are also more influential. ${ }^{61}$ Even indexed funds, which passively track market indices, vote actively on a number of issues. ${ }^{62}$ Finally, because proxy advisors cater to their customers' tastes and expectations, it is ultimately impossible to determine precisely how much advisors influence asset managers or are influenced by them. ${ }^{63}$ According to one study, an ISS advice against the management shifts at most $10 \%$ of votes in U.S. uncontested elections. ${ }^{64}$ Although there are no studies documenting the direct influence of ISS on activists' campaigns, such influence seems to be not as overwhelming as the standard narrative suggests.

56. Communication from the European Commission to the European Parliament, the Council, the European Economic and Social Committee and the Committee of the Regions, Action Plan: European company law and corporate governance - a modern legal framework for more engaged shareholders and sustainable companies, COM/2012/0740, 12 December 2012.

57. E.B. Rock, 'Institutional Investors in Corporate Governance' (21 July 2015). Forthcoming in Oxford Handbook on Corporate Law and Governance, University of Pennsylvania, Institute of Law and Economics Research Paper No. 14-37 (2015), at 13-14.

58. See R.M. Daines et al., 'Rating the Ratings: How Good Are Commercial Governance Ratings?', 98 Journal of Financial Economics 439 (2010).

59. P. Iliev and M. Lowry, 'Are Mutual Funds Active Voters?', 28 Review of Financial Studies 446 (2015), at 453.

60. Ibid., at 455 .

61. S. Choi et al., 'Who Calls the Shots: How Mutual Funds Vote on Director Elections', 3 Harvard Business Law Review 35 (2013).

62. I. Appel, T. Gormley \& D.B. Keim, 'Passive Investors, Not Passive Owners', 121 Journal of Financial Economics 111 (2016).

63. J. McCahery, Z. Sautner \& L. Starks, 'Behind the Scenes: The Corporate Governance Preferences of Institutional Investors', Journal of Finance (2016) [forthcoming], available at: <doi:10.1111/jofi.12393>

64. S.J. Choi, J. Fisch \& M. Kahan, 'The Power of Proxy Advisors: Myth or Reality?', 59 Emory Law Journal 869 (2010).
Activist hedge funds could still avoid a thorough scrutiny by institutional investors if they used a strategy that made them win almost with certainty. This is a second powerful objection to hedge funds activism and is based on the so-called "wolf pack" strategy. ${ }^{65} \mathrm{~A}$ wolf pack is a coalition of hedge funds aimed at maximising the impact of engagement. In the U.S., activists have to disclose their intentions within 10 days of crossing a 5\% ownership threshold. In that time window, hedge funds can profitably increase their ownership, but they do not usually go above $10 \%$. To improve the odds of the engagement, one hedge fund could 'tip' other hedge funds. Or, perhaps more plausibly given the money at stake, other hedge funds may independently decide to jump on the bandwagon and buy stock. In any event, because individual ownership remains below $10 \%$ and hedge funds are not collectively seeking control, wolf packs are immune from allegations of insider trading and of acting in concert for purposes of European takeover regulation.

Wolf packs often operate below the radar, which makes it difficult to estimate their incidence and impact empirically. Still, according to a recent international study, wolf packs account for about $22 \%$ of the overt engagements, increase the success rate (defined as achieving outcomes) from about $46 \%$ to $78 \%$ and are more profitable than individual engagements. ${ }^{66}$ Based on this and other evidence, Professors Coffee and Palia have argued that wolf packs are a nearly riskless strategy for hedge funds to make money. ${ }^{67}$ If the wolf pack puts together about one-third of the votes, as for instance in the Sotheby's case, ${ }^{68}$ they need to get on board another $7 \%-10 \%$ to win. This is about as much as, on average, depends on the recommendation of proxy advisors. This argument suggests that wolf packs will tend to engage corporate management also when it is not efficient to do so.

The impact of wolf packs seems to be overestimated for a number of reasons. First, in more than one-fifth of the wolf packs that could be identified in the aforementioned study, hedge funds have failed to achieve outcomes - hence they have lost money. Second, although wolf pack members increase the success rate by buying from dissatisfied investors, whether the remaining investors are likely to follow ISS or to vote actively is a matter of speculation. Actually, the presence of large investors in the ownership of engaged companies, as in the Sotheby's case, suggests that asset managers who exercise judgment may still be the decisive shareholders. ${ }^{69}$ Third, and most important, $78 \%$ of the overt engagements mapped internationally are not wolf

65. Coffee and Palia, above n. 54 .

66. Becht et al., above n. 6 .

67. Coffee and Palia, above n. 54, at 29.

68. Ibid., at 31-32.

69. R.J. Gilson and J.N. Gordon, 'The Sotheby's Poison Pill Case: The Plate Tectonics of Delaware Corporate Governance' CLS Blue Sky Blog, available at: <http://clsbluesky.law.columbia.edu/2014/05/15/the-sothebys -poison-pill-case-the-plate-tectonics-of-delaware-corporategovernance/> (last visited 21 June 2016). 
packs. There is obviously self-selection here. Hedge funds choose their battles. They decide to join and form a wolf pack only when success is more likely. Likewise, the leading hedge fund, who is getting the lion's share of the wolf pack gains, bears two sorts of risk: first, the risk that others will not join; second, conditional on the previous event, a higher risk of losing the engagement. Engagements without outcomes, with or without wolf packs, deliver insignificant to negative shareholder returns, but still they happen, revealing that hedge fund activism is not risk-free. ${ }^{70}$

The third and most recurrent objection to hedge funds activism is short-termism. Because hedge funds profit from targeting underperforming companies, changing or influencing their management, and reselling the stock at a premium, they may induce the managers to destroy long-term value to maximise short-term stock returns. This argument has several dimensions, which are often confused with each other. The more extreme version of the short-termism argument is that the sizeable shareholder gains brought about by activism are short-lived. ${ }^{71}$ The empirical evidence does not support this part of the claim. However, the empirical evidence can neither support nor reject the short-termism claim in another important dimension. Managers and dominant shareholders subject to market pressure, including shareholder activism and the threat thereof, may be reluctant to invest in projects whose value cannot be incorporated in stock market prices before a few years hence. ${ }^{72}$ Let us discuss the two short-termism critiques in turn.

Two recent studies reject the argument that hedge funds activism make managers go for the 'quick buck' while destroying long-term value. In the first study, Professors Bebchuk, Brav and Jang show that, in the United States, the short-term gains stemming from the announcement of the engagement are not reversed later on. ${ }^{73}$ On the contrary, they document that short-term gains are correct anticipations of the consequences of engagement up to five years hence. ${ }^{74}$ The second study, by Professors Becht, Franks, Grant and Wagner, which also includes non-U.S. activism, confirms that the positive stock returns associated with engagement are not

70. Becht et al., above n. 6 .

71. M. Lipton, 'Current Thoughts About Activism', available at: <http:// corpgov.law.harvard.edu/2013/08/09/current-thoughts-aboutactivism/> (last visited 21 June 2016)

72. A slightly different version of this argument is that hedge funds activism undermines the long-term relationship of managers and controlling shareholders with other stakeholders. See e.g. C. Mayer, Firm Commitment: Why the Corporation Is Failing Us and How to Restore Trust in It (2013). Because this article deals with shareholder feedback in corporate governance, stakeholders are quite out of its scope; but I will, nonetheless, briefly discuss this part of the argument infra, text to notes 121-122.

73. Bebchuk and others, above n. 19.

74. Such long-term consequences are estimated on the basis of accounting and market data for time windows up to five years long. Both tests confirm that the returns are abnormally positive for the companies subject to engagement. Bebchuk and others, above n. 19. short-term. ${ }^{75}$ Activists have an average holding period of 1.7 years, but, more importantly, their buy-and-hold returns are abnormally positive only if outcomes are realised. Therefore, hedge funds are not short-termist in the conventional sense of 'cutting and running.' However, this says nothing about whether the stock markets are myopic relative to some horizon longer than the activists' holding period, ${ }^{76}$ let alone about whether it makes sense to consider such a longer horizon to assess the performance of any particular company.

The limitations of stock market return as performance measure are not the only challenge in ascertaining the desirability of activism. A more fundamental problem for the empirical analysis is that activism produces unobservable effects based on the credible threat of engagement and that the companies that are explicitly engaged are different from those that are not. ${ }^{77}$ Therefore, whether activism increases value compared with an average measure of performance (being that stock market return or some other balance sheet measure) cannot be inferred from the performance of observable activism.

The problem is twofold. For one, we observe only a portion of the true activism, the overt part. This would not be a problem if the distribution between overt and covert activism were random, but it is not. Better managed companies react in anticipation of hedge fund engagement. Moreover, activists go public only when it is in their interest to do so. Keeping the engagement confidential is in the interest of both contestants. The management and particularly the controlling shareholders have less to lose from non-public concessions to the activists, while the latter can make larger profits from those. Activists may have to make their campaign public precisely when the targeted company is more mismanaged, which overestimates the observable returns from engagement.

The second part of the problem is that companies that are or can be targeted by activists differ in several respects from those that are not and cannot be targeted. Consequently, showing that companies successfully engaged outperform a market index, on average, does not really prove that activism improves performance. ${ }^{78}$ It only shows that target companies were undervalued relative to a market benchmark and that activism brings

75. Becht et al., above n. 6. The authors study the long-term results from the announcement to the exit of activist hedge funds, and compare them with the returns of a matching, counterfactual portfolio with no engagement. Such returns are positive so long as there are outcomes of engagement.

76. See infra text to notes 99-107

77. Becht et al., above n. 42.

78. The credibility of empirical analysis is fundamentally based on the definition of a control group, which provides the counterfactual firm to which the firm receiving the treatment - i.e. hedge fund engagement is to be compared in order to establish causality. See Atanasov and Black, above n. 25. Although, more recently, the empirical analyses of hedge fund activism have tried to improve on the identification of causality through matching samples (supra note 27), this does not entirely solve the problem. Matching creates an artefact, which may still differ from the counterfactual firm that has not been engaged, and therefore might not be sufficient to identify causality. 
performance back in line with that benchmark. These studies cannot rule out the possibility that a target company would outperform the benchmark by a larger extent, if not engaged, because this counterfactual company does not exist and if it existed, it would be a different firm. ${ }^{79}$

From this perspective, the crucial conflict underlying hedge funds activism is between two views of the target firm, one by the activists and another by the incumbent management. These views normally differ on strategic issues, such as whether the company should be leaner, more focused on certain businesses and cost-effective in carrying them out, which hedge funds typically like to see. Hedge funds activism can thus be interpreted as a conflict between visions of the same firm, namely a conflict of entrepreneurship. Granted that the empirical evidence cannot tell us which view should prevail, in the next section I turn to theory for indications on how to resolve this conflict efficiently.

\section{Hirschman and the Conflict between Inside and Outside Entrepreneurship}

In his classic, Exit, Voice and Loyalty, Albert Hirschman was concerned with a problem similar to the one motivating hedge funds activism, namely how to avert the decline of a (business) organisation. ${ }^{80}$ Hirschman called this problem 'recuperation', ${ }^{81}$ which he understood as the action to correct temporary lapses in an organisation's efficiency. Therefore, Hirschman's theory can shed light on the conditions that make shareholder activism desirable for the efficiency of corporate governance.

Hirschman distinguished between two feedback mechanisms in organisations. Disgruntled members and customers can exit their organisation, or they can voice their disagreement. The relative desirability of exit and voice depends on which can effectively alert the organisation's management about the need for recuperation. Hirschman's framework applies to several kinds of organisation. In order to discuss the implications for shareholder activism, I will focus on three points he made about exit and voice. First, the optimal mix of exit and voice varies with context. Second, in corporate governance, investors tend to prefer exit to voice. Third, loyalty makes the commitment to voice credible.

According to Hirschman, there is no one-size-fits-all solution to the recuperation problem. Every organisation has an optimal level of exposure to exit and voice, which varies with time. At some point of their life cycle,

79. See Cremers et al. (2016), above n. 27. They find that in the long run, companies that have not been engaged outperform matching companies that have been engaged.

80. The full title of Hirschman's classic (1970), above n. 7, is Exit, Voice, and Loyalty - Responses to Decline in Firms, Organizations, and States.

81. Hirschman, above n. 7, at 3. business organisations may suffer from excessive exit, for instance when tough competition in relatively mature industries gives companies not enough time to realise decline from the exit of customers and shareholders. ${ }^{82}$ In those situations, decline may be averted timely if the management listens to voice. In terms of the modern debate, insensitiveness to voice may lead management to procrastinate the status quo for want of better times, which might never come. I call this problem long-termism, to mirror the short-termism issue more frequently claimed in today's debate. ${ }^{83}$ But, according to Hirschman, voice can be excessive too for a particular organisation, particularly when exit is costly or impossible. Managers' concern with voice by 'captive' customers, members or voters may distract them from the pursuit of efficiency, particularly when uncertainty about the outlook of business is high as opposed to protest being present and concrete. ${ }^{84}$ In the modern parlance, this is a situation in which excessive sensitiveness to voice may lead management to focus on the short-term results necessary to mute the opposing voice. Thus, short-termism and long-termism of management are avoided only if individual companies receive feedback as an optimal mix of voice and exit.

Although Hirschman believed that the optimal feedback mechanism for purposes of recuperation depends on the individual organisation, he was not worried about excessive voice by investors in corporate governance. To the contrary, Hirschman welcomed more voice in business organisations, but typically from customers, because individual investors had rationally a strong preference for the so-called Wall Street Walk, namely exit. ${ }^{85}$ This characterisation of shareholders parallels a long-standing tradition in the corporate governance literature. In a seminal article, Professor Manne famously argued that takeovers, which are based on exit, are superior to proxy fights, which are based on voice. ${ }^{86}$ While markets, including the market for corporate control, are powerful coordination mechanisms, voting is plagued by free riding problems. To be sure, free riding affects takeovers too. ${ }^{87}$ More important, the impact of takeovers and takeover threat on corporate governance may be overstated. On the one hand, decades of experience with takeovers have revealed that they are able to address only severe underperformance. ${ }^{88}$ On the other hand, hostile takeovers are impossible for most companies around the world, and management seems able to always achieve

82. Ibid., at 24-25.

83. However, see the important exception of Giannetti and Yu (2016), discussed above n. 23.

84. Hirschman, above n. 7, at 70.

85. Ibid., at 46.

86. Manne, above n. 31.

87. S.J. Grossman and O.D. Hart, 'Takeover Bids, the Free-Rider Problem, and the Theory of the Corporation', 11 Bell Journal of Economics 42 (1980).

88. P. Bolton, J. Scheinkman \& W. Xiong, 'Executive Compensation and Short-termist Behaviour in Speculative Markets', 73 Review of Economic Studies (2006). 
some degree of insulation from hostile takeovers. ${ }^{89}$ Thus, Hirschman rightly believed that business organisation could use more, not less, shareholder voice to timely avert decline.

Hirschman did not consider shareholder activism a viable channel for voice because he wrote before the rise of hedge funds activism. Entering hedge funds into Hirschman's framework implies both that investors' voice can be effective in corporate governance and that there may be too much of it. Hedge funds engage a company's management by using voice. Their incentives, though, are based on exit, namely on the purchase of undervalued stock from previous shareholders and the sale to future shareholders after a successful engagement. ${ }^{90}$ Voice by institutional investors actually makes the difference because the success of hedge funds activism depends on the voting support by institutional investors. Therefore, to determine whether exposure to hedge fund activism results in efficient feedback, instead of managerial long-termism or short-termism, we need to delve into the incentives of institutional investors to screen and decide on hedge funds' proposals.

Institutional investors differ considerably from one another. These differences affect their incentives to act upon hedge fund engagements. According to Hirschman, the quality of voice depends on the loyalty of a customer or a member to an organisation. Loyalty is, in turn, defined by high cost of exit. ${ }^{91}$ Because costly exit commits shareholders to voice, we can identify loyal institutional investors on the basis of their propensity to exit. In this vein, Professor Bushee divided institutional investors on the basis of portfolio turnover and the size of their stakes in portfolio companies. ${ }^{92}$ Investors are transient when their turnover is high and the stakes are small. Dedicated investors are the opposite. As they focus on specific companies, their stakes are relatively large - although they are still diversified - and they trade relatively infrequently. Quasi-indexers are well exemplified by funds that track market indices, although they include more than strictly indexed funds. Because they mimic the indices they are tracking, such funds trade infrequently and have small stakes in portfolio companies. For the period 1983-2002, Bushee reports that transient investors accounted for $31 \%$ of U.S. institutional investors, whereas dedicated investors and quasi-indexers amounted to $8 \%$ and $61 \%$, respectively. ${ }^{93}$

Although the above percentages are not asset-weighted and thus do not reflect the ownership of a typical U.S. corporation, they show the importance of transient investors. Transient investors are not loyal to any com-

89. J. Arlen and E. Talley, 'Unregulable Defenses and the Perils of Shareholder Choice', University of Pennsylvania Law Review 577 (2003).

90. As Gilson and Gordon, above n. 16, at 897, put it, hedge funds are 'governance entrepreneurs' who profit from purchasing rights undervalued by 'rationally reticent' institutional investors. See also supra text to notes 49-50

91. Hirschman, above n. 7, at 80 .

92. Bushee, above n. 21.

93. B.J. Bushee, 'Identifying and Attracting the "Right" Investors: Evidence on the Behavior of Institutional Investors', 16 Journal of Applied Corporate Finance 28 (2004) pany; hence, they are the least committed to voice. Moreover, transient investors are ready to short-term exit. Therefore, they can cash in the announcement gains from engagement. If a company were owned primarily by them, hedge funds could easily have their way with management through a wolf pack strategy, namely buying collectively sufficient ownership on the market to outvote incumbent managers. ${ }^{94}$ Even before the advent of entrepreneurial activism, disproportionate ownership by transient investors was associated with short-termist managerial behaviour. ${ }^{95}$

If companies are not primarily owned by transient investors, hedge funds activism does not necessarily lead to short-termism because of the screening by other long-term institutional investors. As they focus on the companies they invest in, dedicated investors perform such a screening although they are not to be considered 'loyal' in Hirschman's sense. In fact, they usually govern through exit. ${ }^{96}$ Exit is costlier for dedicated than for transient investors because the larger size of their stakes prevents dedicated investors from profiting from shortterm price movements. However, this is not enough to commit dedicated investors to voice because they are still better off timely exiting the companies they are dissatisfied with. Dedicated investors use their informational advantage to threaten managers with exit and execute the threat when they are persuaded that the company will be actually underperforming. So, in a sense, dedicated investors screen hedge funds activism by preempting it. But if they agree with the reasons for hedge funds engagement, they will rather sell than vote their shares. ${ }^{97}$

That leaves us with just one category of loyal institutional investors, in Hirschman's sense, to screen hedge funds' proposals with their voice. These are the quasiindexers, which cannot exit strategically, but only to rebalance their index-tracking portfolios. Fortunately, they are also the largest category of investors. Although there are currently no data on how large the stake of quasi-indexers is in the typical listed company, it is fair to assume that they are often decisive. ${ }^{98}$ Then the question about the desirability of hedge funds activism could be resolved in the affirmative if one could trust quasiindexers to assess whether hedge funds activism is value-increasing and vote accordingly.

Identifying the right strategy to maximise profit is notoriously difficult. Stock markets are an impressive source

94. See supra text to notes 65-68.

95. Bushee, above n. 21.

96. A. Edmans and G. Manso, 'Governance through Trading and Intervention: A Theory of Multiple Blockholders', 24 Review of Financial Studies 2395 (2011).

97. Recent theory, field data and survey evidence all confirm that dedicated investors participate in corporate governance through exit. See e.g. A. Edmans, 'Blockholders and Corporate Governance', 6 Annual Review of Financial Economics 23 (2014) and McChahery and others, above n. 63.

98. As suggested by the recent DuPont case, where indexed investors such as Blackrock, Vanguard and State Street made the engagement fail, this assumption is plausible at least for the United States. See Coffee, above n. 3. 
of information in this respect, but alas, they are imperfect. ${ }^{99}$ Because they overreact to news, misprice risks and are prone to asset bubbles, ${ }^{100}$ stock market prices may temporarily fail to incorporate the value of future profit opportunities. When this is the case, the Efficient Capital Market Hypothesis (ECMH) does not hold true. ${ }^{101}$ Therefore, there might be a conflict between the pursuit of short-term results, which are immediately impounded in market prices, and long-term projects, whose expected results are underweighted or even overlooked by stock prices. ${ }^{102}$ Short-termism is an issue for corporate governance only if it affects managerial choices. ${ }^{103}$ Hedge funds could lead to short-termism in management because their business model relies on stock market prices - buying undervalued stock and reselling it after successful engagements. If, however, the crucial element of the strategy - engagement's success - depends on indexed funds, the real question becomes whether quasi-indexers too are biased towards short-termism.

The empirical evidence suggests that, under the screening by indexed funds, overt hedge funds activism does not lead to obvious short-termism. As discussed in the previous section, the data show that the short-term gains of successful hedge funds activism are not reversed in the subsequent five years, whereas there are no gains from engagements that turned out unsuccessfully for lack of (prospective) support by institutional investors. However, the performance of overt activism is uninformative about companies that have not been

99. Even before the advent of behavioural finance, it was clear in both the legal and the economic scholarship that informational efficiency was a process rather than an instant result. See R.J. Gilson and R.H. Kraakman, 'The Mechanisms of Market Efficiency', 70 Virginia Law Review 549 (1984), and S.J. Grossman and J.E. Stiglitz, 'On the Impossibility of Informationally Efficient Markets', 70 American Economic Review 393 (1980). Arguably, behavioural finance as well as the debate stemming from the global financial crisis have not changed this basic insight, namely that informational efficiency is a relative concept depending on the speed with which prices adjust to existing knowledge. See R.J. Gilson and R.H. Kraakman, 'Market Efficiency after the Financial Crisis: It's Still a Matter of Information Costs', 100 Virginia Law Review 313 (2014).

100. The main problems undermining the efficiency of financial markets are limits of arbitrage (A. Shleifer and W. Vishny, 'The Limits of Arbitrage', 52 Journal of Finance 35 (1997)), excess volatility (A. Fuster et al., 'Natural Expectations, Macroeconomic Dynamics, and Asset Pricing', National Bureau of Economic Research Working Paper No. w17301 (2011)) and asset price bubbles (Bolton and others, above n. 88, at 577).

101. The ECMH is based on arbitrage. A fundamental principle of economics is that arbitrageurs would never forego a profit opportunity so long as they can grab it. When they cannot, because for instance they are capital constrained or there is uncertainty, price may deviate from fundamentals. Until this situation is corrected, market may overvalue shortterm strategies and undervalue long-term strategies. Although this difference will be arbitraged away, eventually, long-term value might be destroyed in the process.

102. See A.G. Haldane and R. Davies, 'The Short Long', 29th Société Universitaire Européene de Recherches Financiéres Colloquium: New Paradigms in Money and Finance?, Brussels (2011) for extensive illustration of theory and evidence on the short-termism of financial markets.

103. The short termism of financial market does not necessarily imply that corporate managers are short-termist and, even more important, that short-termism is undesirable for corporate governance. See Roe, above n. 15 . engaged, and therefore cannot lead to a conclusive judgment about hedge funds activism. A recent study reveals that in the long run the performance of engaged companies is lower than that of comparable companies that were not engaged. ${ }^{104}$ Moreover, the question whether the sheer threat of activism induces short-termism in management and whether this is desirable cannot be answered empirically. I now turn to the reasons why theory too does not provide a unique answer to this question.

To begin with, short-termism is ill-defined. Because short-termism is an issue only if the ECMH fails, the value of a long-term option is defined only by what it is not: the market price failing to incorporate it. As a result, opinions of reasonable minds differ as to which long term is 'right' for purposes of profit maximisation. Second, even if one could settle on a conventional definition of long term (say, five years), companies oriented to the long term would be radically different from those oriented to a shorter term. Comparing the returns of these companies on horizons different from what they have chosen is not very meaningful. ${ }^{105}$ Third, whether managing for the long term or the short term is preferable is theoretically unclear. Professor Fried has shown that, under certain conditions, pursuing the interest of long-term shareholders can lead management to destroy more value than if they managed in the interest of shortterm shareholders. ${ }^{106}$ More importantly, the 'right' horizon to maximise profit is endogenous to the company's business and the state of product market competition. Whether managers suffer from short-termism or long-termism relative to this horizon depends on company-specific circumstances. ${ }^{107}$

As recently put by Professor Gordon, the short-termism debate on hedge fund activism is a red herring for a deeper corporate governance problem. ${ }^{108}$ The problem is in determining who should decide between alternative company strategies, each implying different horizons for feedback. I call this problem a conflict of entrepreneurship because it stems from two conflicting, potentially entrepreneurial views of the target company - the view of the activists versus that of the incumbent management. Such views are entrepreneurial to the extent that they reflect a shortcoming of stock prices rather than managerial opportunism. The stock price cannot fully

104. See Cremers et al., above n. 27 (using several matching techniques to compare companies engaged and not engaged by hedge funds). On the limitations of matching methods to identify causality between hedge funds activism and firm variables, see supra note 78 .

105. On these grounds, the findings of Cremers et al., above n. 27, are as questionable as those of their opponents (Bebchuk and others, above $\mathrm{n}$. 19). In fact, as argued below in the text, the optimal horizon to maximise profits is endogenous to firm-specific circumstances.

106. Fried, above n. 22.

107. Giannetti and Yu, above n. 23, show that long-termism undermines the ability of companies to deal with a highly dynamic and competitive environment.

108. J.N. Gordon, 'Shareholder Activism, the Short-Termist Red-Herring, and the Need for Corporate Governance Reform', available at: <http:// clsbluesky.law.columbia.edu/2016/03/28/shareholder-activism-theshort-termist-red-herring-and-the-need-for-corporate-governancereform/> (last visited 17 June 2016). 
account for the future because it is uncertain. Uncertainty is for entrepreneurs, not for markets, to bear. ${ }^{109}$

According to two prominent students of uncertainty Frank Knight and John Maynard Keynes - financial markets are only one way to deal with uncertainty, by incorporating all available information into a probabilistic risk assessment. ${ }^{110}$ Because nobody knows how a distant future, call it 'long term', will look like, stock markets process information within a relatively short horizon, in which no change from established trends can be assumed. The vast majority of investors make decisions under the same assumption, which is thus reflected by market prices too. The role of the entrepreneur is to deal instead with genuine uncertainty that, differently from risk, cannot be quantified. Entrepreneurship is based on long-term expectations, which incorporate all information available to financial markets, but differ from market price in one fundamental respect: they also include a guess about forthcoming change. ${ }^{111}$ Therefore, when hedge fund activists and their opponents advocate two different strategies to 'beat the market', the discussion about the right horizon to assess performance may conceal a conflict between entrepreneurs having a different opinion about changes and their impact on performance. From this perspective, quasi-indexers become decisive between two entrepreneurial views on how the target company should move forward. Whether they are the right arbiters for this choice depends on context.

One strategic issue on which the views of activists and incumbent management often collide is quality and quantity of R\&D expenditures. The incumbent management usually asks for the return on $\mathrm{R} \& \mathrm{D}$ expenditures to be assessed over a longer horizon. Activist hedge funds, instead, want the companies to be leaner and more focused on developing specific products, which usually results in cuts of R\&D and personnel expenditures and larger short-term profits. ${ }^{112}$ Overall reduction of R\&D expenditures does not necessarily imply that the company is less innovative. ${ }^{113}$ A recent study shows that activism can improve productivity and R\&D output on several counts. ${ }^{114}$ Still, granted that activism tends to reduce $\mathrm{R} \& \mathrm{D}$ input, this may not be the right choice for a number of companies. Another theoretical study, unrelated to activism, reveals that different kinds of innovation benefit from different organisational forms. ${ }^{115}$ In particular, complex innovations with long life cycles benefit from conglomerate structures in which R\&D can be redirected internally from a project to another. Those are precisely the structures that activists seek to break up.

109. See supra note 28 and accompanying text.

110. Knight, above n. 28, at 233-63; and J.M. Keynes, 'The General Theory of Employment', 51 Quarterly Journal of Economics 209 (1937).

111. See Keynes, above n. 28, at 96-106.

112. Coffee and Palia, above n. 54.

113. Bebchuk and others, above n. 19

114. Brav et al., above n. 27.

115. S. Belenzon, P. Bolton \& U. Tsolmon, 'The Organization of Innovation across Countries and Industries', Unpublished Working Paper, Duke University (2013)
Indexed funds are unlikely to stop hedge funds whenever saving on R\&D expenditures appears to be the wrong strategy. The empirical evidence is that, although institutional investors generally support $\mathrm{R} \& \mathrm{D}$ investments, this support does not stem from quasi-indexers. ${ }^{116}$ This aligns with theory. Quasi-indexers are highly diversified investors that do not benefit from firm-specific screening. Because their income depends on the assets under management, they choose low-cost voting policies that the market appreciates overall, including best practices in corporate governance and/or in a particular industry. ${ }^{117}$ Arguably, indexed funds decide whether to support hedge funds based on the same criteria. Whether the target company should engage in linear or nonlinear innovation is a much more idiosyncratic question that quasi-indexers are not interested in answering.

Relying on the judgment by quasi-indexers is efficient in other situations. Not all instances of stock market underperformance that trigger hedge funds activism really depend on strategic choices. Often the matter is much simpler, namely whether the controlling management is wasting resources. There the advantage of quasi-indexers' voting in a standardised, predictable fashion on a hedge fund's memo showing waste is that they can commit the company's management to refrain from opportunism. This commitment is valuable, because it makes investors more willing to invest in the first place. Facing the threat of hedge funds teaming up with institutional investors, managers have to be more careful about misusing fee cash or being unresponsive to the competitive environment. In the absence of such 'recuperation mechanism,' as Hirschman put it, excessive consumption of perquisites, pet projects, if not empire building, could dissipate enormous value until the company is bankrupt or is acquired. Hedge funds activism can stop this well before the decline becomes irrecoverable. Moreover, because entrepreneurial activism is a credible threat in all countries where declining companies can be engaged, even dominant shareholders may have to refrain from self-dealing for fear of engagement by hedge funds.

As the example of R\&D expenditures shows, the commitment towards outside investors supported by hedge funds activism risks becoming excessive when the reason for the activists' targeting a company is disagreement about the company's strategy. In such a situation, the strategy proposed by hedge funds in opposition to

116. See P. Aghion, J. van Reenen \& L. Zingales, 'Innovation and Institutional Ownership', 103 American Economic Review 277 (2013). This study utilises an interesting strategy to identify causality. Companies' inclusion into market indices arguably matters for the investment by index trackers, but it is unlikely to affect R\&D expenditures via other channels. Based on a similar identification strategy, another study reports a statistically insignificant impact of quasi-indexers on R\&D (Appel and others, above n. 62), although according to a different study the presence of long-term indexers reduces R\&D expenditures. See J. Harford, A. Kecskes \& S. Mansi, 'Do Long-Term Investors Improve Corporate Decision Making?', Finance Down Under 2015 Building on the Best from the Cellars of Finance Paper (2015), available at <http://ssrn.com/ abstract=2505261 > (last visited 21 June 2016).

117. Appel and others, above n. 62, at 113 . 
the incumbent management is particularly difficult to evaluate. Moreover, the judgment of 'loyal' investors such as indexed funds cannot be relied on because the question is not simply whether existing resources are being managed efficiently, but rather how resources should be directed towards an uncertain future. This is an entrepreneurship question that indexed funds, with their typically small stakes in a particular company, do not have the expertise and the incentives to answer. In this respect, indexed funds crucially differ from venture capitalists, which specialise in dealing with entrepreneurship questions. ${ }^{118}$

If not the 'loyal' institutional investors, who should decide whenever hedge funds activism triggers a conflict of entrepreneurship? As Professor Mayer recently put it, there is a trade-off between commitment and control in corporate governance, and we should let individual companies decide which mix suits their circumstances best. ${ }^{119}$ In Mayer's framework, control is understood as commitment to one particular constituency, namely commitment to outside investors. Another way to put the trade-off is whether the company should commit to the feedback engineered by entrepreneurial activists or to something else, for instance the entrepreneurship of inside management. ${ }^{120}$ More in general, some companies may benefit from less investors control and more commitment to stakeholders other than the shareholders, including employees, creditors and entrepreneurs. ${ }^{121}$ Similarly to Mayer, this article contends that companies should decide 'who decides' in the event of hedge fund engagement. Differently from Mayer, however, this article argues that the dilemma about hedge funds activism is only whether a company should commit to inside or outside entrepreneurship, not to any other stakeholder. Here I follow the standard corporate governance argument against the inclusion of stakeholders in the company's objective function. This argument is twofold. ${ }^{122}$ First, differently from shareholders, stakeholders can protect themselves through contracts. Second, the externalities of a business on stakeholders do not depend on corporate governance and therefore should not be addressed by corporate governance regulation. None of these arguments apply to entrepreneurship. Entrepreneurs cannot effectively protect their investment by contract. Moreover, lack of entrepreneurship in listed companies is a direct consequence (negative externality) of corporate governance. On this basis, in the next section, I will discuss how corporate law can support entrepreneurship by allowing companies to choose the desired degree of exposure to activism and to alter it over time.

118. See R.J. Gilson, 'Engineering a Venture Capital Market: Lessons from the American Experience', 55 Stanford Law Review 1067 (2003).

119. Mayer, above n. 72 , at 234-36.

120. In the past, I have framed this as a trade-off between (entrepreneurial) discretion and (market) accountability. See Pacces, above n. 29, at 145-46.

121. Mayer, above n. 72 , at $152-53$.

122. See Pacces, above n. 29 , at 74-82.

\section{Evaluating the Policy Options}

The policy debate on shareholder activism differs considerably from the foregoing discussion. Prompted by the standard narrative about the global financial crisis, policymakers hold institutional investors (including hedge funds) responsible for short-termism in corporate governance. $^{123}$ Ideally, policymakers would like to replace hedge funds' influence with the engagement of longer-term shareholders, regarded as more 'loyal,' albeit not exactly in Hirschman's sense. As we have seen, however, loyalty is no panacea. Neither is longterm ownership. This point is widely acknowledged also by academics sympathetic to the short-termism argument. ${ }^{124}$ While these commentators argue that companies under the influence, or threat, of hedge funds activism cater to the short-termism of the stock market, they recognise that very many companies benefit from short-term market pressure. Companies that suffer from this pressure, however, should be able to effectively opt out of hedge funds' influence. Other commentators disagree with this point, claiming that short-termism is not a problem for anyone but the incumbent managers who seek insulation from activism, as previously from hostile takeovers, in order to disenfranchise the shareholders. ${ }^{125}$ Having argued that the short-termism debate cannot shed light on the limitations of shareholder activism, I will analyse the main policy proposals to curb activists' powers from the perspective of conflict of entrepreneurship.

The first set of proposals concern the disclosure of activists' ownership. ${ }^{126}$ Activists' business model is fundamentally based on the purchase of undervalued stock (a so-called "toehold") while the market is still in the dark about the hedge fund's intentions. Thus, the obvious way to undermine activism is to reduce the size of the toehold that can be purchased profitably. Ownership disclosure regulation can have this chilling effect through the following policy variables ${ }^{127}$ : (a) the threshold above which ownership needs be disclosed; (b) the time window available to activists since the crossing of the threshold; (c) the regulatory treatment of groups of activists. In the extreme, if a block larger than, say, $0.5 \%$ had to be disclosed within an hour of crossing the threshold by any group of shareholders intending to

123. See e.g. European Parliament, Amendments adopted by the European Parliament on 8 July 2015 on the proposal for a directive of the European Parliament and of the Council amending Directive 2007/36/EC as regards the encouragement of long-term shareholder engagement and Directive 2013/34/EU as regards certain elements of the corporate governance statement, 2014-2019, P8_TA(2015)0257 (hereinafter EP Amendments 2015).

124. See Bolton and Samama, above n. 18; Mayer, above n. 72.

125. See, most vigorously, L.A. Bebchuk, 'The Myth That Insulating Boards Serves Long-Term Value', 113 Columbia Law Review 1637 (2013).

126. See supra text to notes $16-17$.

127. See L. Enriques, M. Gargantini \& V. Novembre, 'Mandatory and Contract-Based Shareholding Disclosure', 15 Uniform Law Review 713 (2010) for a similar argument applied to takeovers. 
vote against the management, hedge funds activism would likely disappear. Proposals along these lines, albeit less extreme, have been aired in the American debate but, partly owing to wide opposition by authoritative academics, the SEC is no longer considering changing the status quo. ${ }^{128}$ A 5\% threshold, a 10-day window to disclose it and the irrelevance of conscious parallelism in voting still make the U.S. legal environment one of the most favourable to shareholder activism worldwide. Many jurisdictions in Europe impose a lower threshold and a shorter window. ${ }^{129}$ Note that, in Europe, the discussion about tightening ownership disclosure regulation is still ongoing. ${ }^{130}$

If we look at shareholder activism through the lens of conflict of entrepreneurship, curbing one of the opposing entrepreneurial activities, namely hedge funds activism, is not the way to solve the conflict. This approach would be economically justified only if hedge funds activism was on average detrimental to shareholder value, whether because of short-termism or otherwise. As shown in Section 2, this claim is not borne out by the empirical evidence, which actually suggests the opposite. However, the sheer threat of activism - whose effects are unobservable - could still be value-destroying if some of the activists' strategies were nearly riskless, as Professors Coffee and Palia have argued wolf pack strategies are. ${ }^{131}$ Albeit impossible to falsify empirically, this claim seems as overstated as the actual impact of wolf packs. ${ }^{132}$ Engagements by wolf packs remain a risky strategy that do not lead to obvious short-termism, for arguably, institutional investors would not support value-destroying engagements and, under this expectation, wolf packs would not be formed in the first place.

To be sure, as argued in the previous section, hedge funds activism could induce management to choose short-term strategies that are suboptimal for the particular company. Wolf packs would make this problem worse. However, from a conflict of entrepreneurship perspective, mandatory rules to curb the power of wolf packs, such as the inclusion of the group members in the leading activist's disclosure, are unwarranted. Companies that want to discourage activism, whether individual or in concert, have plenty of ways to do so. Countermeasures range from low-trigger poison pills (in the United States), ${ }^{133}$ to functionally equivalent dilutive techniques in those jurisdictions where they are allowed

128. See Coffee and Palia, above n. 54.

129. For instance, Germany, Italy, the Netherlands and the UK feature a $3 \%$ threshold and an obligation to disclose that varies between 2 and 4 days. See Gilson and Gordon, above n. 16.

130. A proposal was made recently by the Legal Affairs Committee of the European Parliament to mandate disclosure above $0.5 \%$. See Cofferati Report (2015), above n. 12. This proposal, however, was not included in EP Amendments (2015). The discussion between the EU institutions on this and related curbs on shareholder activism is still ongoing at the time of writing.

131. Coffee and Palia, above n. 54, at 29.

132. See supra text to notes 69-70.

133. Coffee and Palia, above n. 54, at 32. However, also see Gilson and Gordon, above n. 69, on the unimportance of the poison pill when hedge funds garner sufficient support from the institutional investors. (e.g. the Netherlands), ${ }^{134}$ to dual-class shares, which in one way or another can be engineered nearly everywhere. ${ }^{135}$ Importantly, activism is also observed in the presence of these countermeasures. ${ }^{136}$

The fundamental argument of this article is that hedge funds activism should be evaluated in the specific context in which it operates. For some companies, in a certain stage of their life cycle, exposure to activism is efficient; for others, or for the same companies at another point in time, it is not. From this perspective, the more interesting proposals in the policy debate are those offering individual companies instruments to tailor exposure to activism to their circumstances, for instance depending on whether it is optimal for them to profile on short-term or longer-term strategies.

Seemingly, one instrument for companies to tailor exposure to hedge funds activism is rewarding shareholders who were, or will be, invested in the company for some time with a higher voting power. ${ }^{137}$ These shareholder voting structures are known under various names, but perhaps the better known designation in Europe where they have been most popular of late - is 'loyalty shares.' ${ }^{138}$ Although their assonance with Hirschman's framework is accidental, the function of loyalty shares is much in the spirit of Hirschman's argument that voice

134. Dutch preference shares are functionally equivalent to U.S. poison pills, and can be used to fend off both hostile takeovers and activism. See L. Chazen and P. Werdmuller, 'The Dutch Poison Pill: How Is It Different from an American Rights Plan?', available at <https://corpgov.law. harvard.edu/2015/12/01/the-dutch-poison-pill-how-is-it-different-from -an-american-rights-plan/> (last visited 21 June 2016).

135. See R. Adams and D. Ferreira, 'One Share-One Vote: The Empirical Evidence', 12 Review of Finance 51 (2008). The recent history of corporate mobility also reveals that companies who want dual class shares simply move to jurisdictions allowing them. See M. Ventoruzzo, 'The Disappearing Taboo of Multiple Voting Shares: Regulatory Responses to the Migration of Chrysler-Fiat', ECGI Working Paper Series in Law No. 288/2015. In the UK, the moves towards control enhancement of dominant shareholdings have triggered a tightening of (the Premium segment of) the listing regime, which has been criticised by some commentators. See B.R. Cheffins, 'The Undermining of UK Corporate Governance (?)', 33 Oxford Journal of Legal Studies 503 (2013) and R. Barker and I.H-Y. Chiu, 'Protecting Minority Shareholders in BlockholderControlled Companies: Evaluating the UK's Enhanced Listing Regime in Comparison with Investor Protection Regimes in New York and Hong Kong', 10 Capital Markets Law Journal 98 (2015).

136. On activism in controlled companies, see K. Kastiel, 'Against All Odds: Shareholder Activism in Controlled Companies' (2015), available at <http://ssrn.com/abstract=2628987> (last visited 22 June 2016). See also supra note 5 .

137. Reward can be in terms of voting rights or cash-flow rights. Because most of the policy and academic debate has been on rewarding longterm shareholdings by means of voting rights, this article also focuses on voting power. However, it is important to note the prominent exception of Bolton and Samama, above n. 18, who have proposed to incentivise long-term shareholding exclusively by means of extra cashflow rights.

138. See J. Delvoie and C. Clottens, 'Accountability and Short-Termism: Some Notes on Loyalty Shares', 9 Law and Financial Markets Review 19 (2015). However, see also, for the United States, the functionally equivalent expressions 'Time-Phased Voting' and 'Tenure Shares'. See respectively L. Dallas and J.M. Barry, 'Long-Term Shareholders and Time-Phased Voting', Delaware Journal of Corporate Law (DJCL) (2015); and D.J. Berger, S.M. Davidoff \& B.A. Jedidiah, 'Tenure Voting and the US Public Company' (2016), available at: <http://papers.ssrn. com/sol3/papers.cfm?abstract_id=2740538> (last visited 22 June 2016). 
can be excessive for a particular organisation. Loyalty shares are there to curb hedge funds activism in the companies that adopt them. The requirement of loyalty is the least important part of their effectiveness, although it has undoubtedly contributed to make loyalty shares politically palatable.

Loyalty shares are a French invention. While prohibiting multiple voting shares, French law allowed companies to grant one additional vote to shareholders that had held shares continuously for two years. This was optional for every French company until, in 2014, the Loi Florange made loyalty shares the default regime for listed companies. This move has virtually imposed loyalty shares on existing listed companies. Companies that did not have loyalty shares in place automatically got them, unless they opted out of the default rule. However, opting out of loyalty shares requires an amendment of the articles of association, which in France is governed by a two-third majority and hence can be vetoed by only one-third of the votes. Therefore, dominant shareholders could push loyalty shares despite the opposition of institutional investors, as the French government did recently in the Renault case. ${ }^{139}$

Loyalty shares have been popular elsewhere in Europe. Fiat-Chrysler Automobiles (FCA), Italy's largest family-owned corporation, reincorporated to the Netherlands allegedly in order to adopt loyalty shares, which were not allowed in Italy. ${ }^{140}$ Subsequently, Italian law was amended and now allows listed companies to opt into French-style loyalty shares with a two-third majority. Italy allowed companies to amend their articles with a simple majority for a transition period, whose prolongation was stopped by the opposition of institutional investors and several academics, including the author of this article. ${ }^{141}$ It is noteworthy that, in Europe, loyalty shares have been typically implemented by existing companies in the midstream, with dominant shareholders being decisive, although formally all shareholders fulfilling the loyalty requirements qualify for the extra vote(s).

Loyalty shares are appealing because they seem to empower all shareholders equally on a dimension other than the size of their investment, namely the time of their investment. Loyalty shares are thought to rebalance shareholder powers from activists to long-term investors. On the assumption that hedge funds activism leads to short-termism and that the latter is always detrimental for a company, policymakers, including some members of the European Parliament, advocated the introduction of loyalty shares across the European

139. See 'Shareholders Rights in Europe - Short-Term or Short-Changed?', The Economist (May 2, 2015).

140. Ventoruzzo, above n. 135

141. See the text of the petition and the response by the Italian Ministry of the Economy at <http://oneshareonevote.org> (last visited 17 June 2016).
Union. ${ }^{142}$ Similarly, academics have argued that allowing companies to opt into loyalty shares or other timevarying voting system would cope with short-termism precisely when it is detrimental. Surprisingly, however, institutional investors - including the owners that would qualify for the loyalty benefits - almost invariably oppose the introduction of loyalty shares.

Loyalty shares are not as good as they look, and they look different from what they are. To start from their flaws, loyalty shares do not really commit to anything, let alone to long-term strategies. Having held shares for any number of years says nothing about for how much longer investors will hold them, although this is crucial for their voting strategy. To cope with this problem, Professor Mayer proposed to allow companies to give voting rights proportional to a residual holding period to which investors commit ex ante. Super-voting loyalty shares would be inalienable for the committed period, and could only be redeemed prior to maturity at a penalty in terms of both price and voting rights. ${ }^{143}$ Although ingenious, this proposal has a few shortcomings that are hard to overcome.

To begin with, the link between voting rights and holding periods, whether past or future, can be circumvented so long as disclosure of the ultimate beneficial ownership can be avoided. An intermediary company could qualify for the loyalty benefits by locking in ownership, but defer to its beneficial owners for how to vote the loyalty shares. Such beneficial owners, who could be transient investors, will de facto control the extra voting rights. To be sure, several mechanisms have been proposed to track loyalty to the beneficial owners, for instance special rules to register the loyalty shares as a precondition for enjoying their benefits. ${ }^{144}$ In consideration of the administrative costs, the French legislator has decided to drop those mechanisms. ${ }^{145}$ Moreover, in the absence of a case-by-case screening, which would require board discretion and thus expose to directors' opportunism, curbs on shareholders' arbitrage of voting rights are unlikely to work. As the experience with hedge funds activism suggests, the arbitrage of governance rights can be so profitable that it is difficult to imagine low-cost solutions that could cope with it. ${ }^{146}$

142. This proposal, originally included in the Cofferati Report (2015), above n. 12, has disappeared from the official documents. However, it is still being considered. See K.J. Hopt, 'Corporate Governance in Europe: A Critical Review of the European Commission's Initiatives on Corporate Law and Corporate Governance', 12 New York University Journal of Law \& Business 139 (2015), at 158.

143. See Mayer, above n. 72, at 265.

144. See Bolton and Samama, above n. 18; Berger et al., above n. 138

145. Delvoie and Clottens, above n. 138, at 28.

146. Mayer, above n. 72 , at 266-67, is more optimistic about the possibility to stop the arbitrage of voting rights between long-term shareholders and short-term beneficial owners. In his view, linking the extra voting rights to a future holding period makes it progressively more difficult for short-term beneficial owners to create liquidity through policies that undermine long-term returns - in the last period, it may be difficult for owners to sell shares whose long-term value has been undermined. This argument neglects the impact of stock market bubbles, which can go on for several years. As shown by $\mathrm{H}$. Minsky, in Stabilizing an Unstable Economy (1986), refinancing debt can prop up asset prices (including stock prices) indefinitely, until a debt crisis occurs. 
Furthermore, loyalty shares committing to a holding period entrench control. For instance, in the event of a takeover, only the shareholders loyal to the management would retain the extra voting rights; that might be enough to fend off a hostile bid. There are ways to get around this problem, but they all would make loyalty shares less attractive. For example, Eumedion - a Dutch foundation representing the interests of several institutional investors - proposed to cap the extra voting rights at $5 \%$ in order to prevent dominant shareholders from using loyalty shares as a control enhancing mechanism. ${ }^{147}$ On a different note, having in mind shares rewarding loyalty exclusively with pecuniary benefits, professors Bolton and Samama suggested making such benefits expire in the event of a takeover bid. ${ }^{148}$ Whereas a similar contingency approach could be applied to voting rights, it is very doubtful that loyalty shares would be as attractive if deprived of their entrenchment effect.

Loyalty shares are effectively dual-class shares in disguise. Formally, loyalty shares look different from dualclass shares because they allocate superior voting rights to any investor fulfilling the holding period requirements attached to them, not just to the holder of a specific class of shares. Hence, loyalty shares look like a remedy against short-termism, not an entrenchment device for managers or controlling shareholders. ${ }^{149}$ In reality, loyalty shares are attractive precisely when they operate as dual-class shares. Loyalty shares are uninteresting for institutional investors. Transient investors do not care about loyalty. The commitment of quasi-indexers is independent of their voting rights, and they may forego loyalty benefits simply because of portfolio rebalancing. Only dedicated investors could be potentially interested. However, as we have seen, dedicated investors rather govern through exit. Hence, they would not accept committing to loyalty for extra voting rights, if that cost them the exit option. There remain only shareholders interested in control to profit from loyalty shares, namely the management and/or the dominant shareholders. While non-controlling shareholders are unlikely to care for the extra voting rights, the incumbents can use loyalty shares as super-voting shares against activist hedge funds who can only have access to

147. See Eumedion, 'Draft Position Paper on The Position of Minority Shareholders in Companies with a Dominant Shareholder' (15 October 2015), available at <http://eumedion.nl/en/public/knowledgenetwork/ position-papers/2015-10-draft-position-paper-protection-minorityshareholders.pdf> (last visited 3 July 2016). The Dutch government, however, sounded disinclined to adopt this proposal on the grounds that it would not necessarily fit the needs of some companies. Interestingly, the final version of Eumedion, Position Paper on The Position of Minority Shareholders in Companies with a Dominant Shareholder (26 June 2016), available at <http://eumedion.nl/en/public/ knowledgenetwork/position-papers/2016-06-position-paper-minorityshareholders-final-version.pdf> (last visited 3 July 2016), does no longer include the proposal to cap the extra voting rights at $5 \%$, but goes rather in the direction of the policy recommendations of this article (approval of the restriction by the majority of the minority and sunset clauses - see below in the text).

148. Bolton and Samama, above n. 18.

149. See Dallas and Barry, above n. 138. common stock. This makes sense from a perspective of conflict of entrepreneurship. Companies that want to commit to the incumbents' as opposed to the activists' entrepreneurship will go for loyalty shares. Because this strategy undermines the overall impact of institutional investors, it is no surprise that also long-term investors oppose loyalty shares. What is unclear at this point is why the incumbent management prefers loyalty shares to classic dual-class shares structures.

A key difference between dual-class shares and loyalty shares is that only the latter can be introduced in the midstream. A founder concerned with the adverse impact of activism on certain styles of innovation could simply go public with dual-class shares, which companies increasingly do. ${ }^{150}$ When the managers of an already listed company have the same concern, they cannot introduce a super-voting class of shares even with a favourable shareholder vote. Dual-class recapitalisations that exchange existing shares for two classes of shares, one with higher voting rights for the controlling group and one with lower voting rights for the investors, are not allowed either in Europe or in the United States. ${ }^{151}$ Loyalty shares are a way out of this bind. Because formally they do not discriminate among shareholders, companies can issue them in the midstream. In the United States, this is part of the history of loyalty shares, which were all introduced in the short time when it was unclear whether dual-class recapitalisations were allowed. ${ }^{152}$ Moreover, according to some commentators, introducing loyalty shares is still possible in the United States despite the exchanges' prohibition of recapitalisations, so long as no existing shareholder is worse off. ${ }^{153}$ In Europe, room for loyalty shares has been created by national legislatures, where it did not exist before, and may be furthered by the European Union. But this has created the paradox, revealed by the French and partly the Italian experience, in which loyalty shares may be introduced despite the opposition of a majority of institutional investors.

It would be better to allow dual-class recapitalisations explicitly and regulate them in such a way as to avoid misuse by incumbent managers and controlling shareholders. The potential for misuse is significantly reduced if investors have veto power on the transaction. In the past, commentators were concerned that investors could be coerced into voting for recapitalisations because of their inability to coordinate. ${ }^{154}$ The re-concentration of ownership by institutional investors has

150. See e.g. Enriques and others, above n. 32 (reporting 170 U.S. companies going public with dual-class shares between 2010 and 2012). See also supra, note 135 (Outside the United States, companies can choose to incorporate in a jurisdiction allowing dual-class shares).

151. See G. Ferrarini, 'One Share-One Vote: A European Rule?', 3 European Company and Financial Law Review 147 (2006).

152. Dallas and Barry, above n. 138. According to the letter of the listing rules, the midstream introduction of loyalty shares is currently not allowed in the United States. But see the argument below in the text.

153. Berger et al., above n. 138.

154. See R.J. Gilson, 'Evaluating Dual Class Common Stock: The Relevance of Substitutes', 73 Virginia Law Review 807 (1987) for a critical discussion of the argument. 
made such worries much less compelling. Therefore, dual-class recaps could be allowed subject to a majority of minority (MOM) vote. This solution would not only provide sufficient guarantees to minority shareholders; it would also screen for situations in which dual-class shares are efficient from the perspective of conflict of entrepreneurship. Managers and controlling shareholders are naturally inclined to curb shareholder powers, particularly in the midstream, when investors cannot collectively withdraw equity. However, a MOM vote requires the proponent to signal that the restriction is value-increasing in order to gain the approval by minority shareholders.

The one-share-one-vote regime (1S1V) should not be a constraint on the flexibility of established listed companies, but rather become a 'sticky default', as Professor Ayres put it. ${ }^{155} \mathrm{~A}$ sticky default is a quasi-mandatory rule that, by design, is expensive to alter for the average person or company. The purpose of sticky defaults is to enable opt-out only by those parties for which the default rule would be inefficient, because otherwise the cost of opting out would outweigh the benefits. If the management wants to introduce dual-class shares to take advantage of minority shareholders, the latter will not consent unless they are paid the full expected value of expropriation. Conversely, the management of a company with a project that could take too long for the market to appreciate may derive net benefits from persuading institutional investors to enter into a dual-class recapitalisation. Because institutional investors will typically have a policy against dual-class shares, management will have to commit to a value-increasing strategy. The key question is, then, what commitment is likely to persuade institutional investors to accept the deal.

The baseline to compare this hypothetical contract is a going private transaction, which could likewise enable a dual-class recapitalisation. ${ }^{156}$ Going private requires the management to find a financier, for which they will have to commit their personal wealth and offer sufficient guarantees to outside investors. As founders commit their private wealth when they go public with a dualclass voting structure, by investing sufficient capital in Class-A shares, so could the management or the dominant shareholders of an already listed company. In the midstream, additional guarantees may be needed to persuade institutional investors, thereby saving on the cost of taking the company private. First, controllers will want to commit against self-dealing for as long as they retain extra voting rights. Minority board representation is a credible signal for this, because by sitting on the board, investors' representatives can stop expropriation in most western jurisdictions. ${ }^{157}$ Minority board seats,

155. See Ayres, above n. 34, at 2032, 2084-88 on 'Impeding altering rules' 156. Another way to do it is by reincorporation, which is comparable to the solution being advocated in this article, because it requires a favourable vote by minority shareholders.

157. On the role of minority-appointed directors to curb self-dealing, see A.M. Pacces, 'Controlling the Corporate Controller's Misbehaviour', 11 Journal of Corporate Law Studies 177 (2011) (assuming that courts are sufficiently reliable to enforce the appointment of minority directors). however, are not enough to undermine long-term strategies. Second, in order to commit against a never-ending long-term, which investors would not accept, the restriction to protect insiders' entrepreneurship could be time-bound. Dual-class shares could be set to expire in a horizon agreed upon, during which the goals of the project are realised or clearly become unattainable. ${ }^{158}$ This would commit prospective controllers against empire building and similar conflicts of interest.

This reasoning reveals that the combination of a $1 \mathrm{~S} 1 \mathrm{~V}$ default with a MOM rule for altering it provides an advantage that loyalty shares only have in theory: the temporary character of control enhancement. ${ }^{159}$ It is often argued that because loyalty shares confer benefits depending on a holding period, eventually there will be no disproportionality between ownership and voting rights among loyal shareholders. In practice, this never leads to the elimination of control enhancement because, as explained, institutional investors cannot commit to the same loyalty as a controlling shareholder. On the contrary, having to negotiate with institutional investors the midstream introduction of dual-class shares, managers and dominant shareholders must likely commit to sunsetting disproportional voting structures.

A major disadvantage of dual-class shares and entrenched control structures in general is that they are difficult to remove once they are established. This may lead to inefficiency because the same company that once benefited from entrenched control may suffer from it later on. The need for controllers to offer investors a sunset arrangement to enable a dual-class recapitalisation overcomes this problem. As the recent U.S. experience with the poison pill suggests, institutional investors can be talked into accepting control enhancements only when these are temporary. ${ }^{160}$ So if, within a limited period, the entrepreneurial project succeeded, both controlling and non-controlling shareholders would make their profits and the dual-class structure could be collapsed. If, instead, the project failed, the expiration of the dual-class structure would make it easier to reallocate control of the company's assets, with or without the intervention of activists or hostile bidders. Therefore, the sticky default approach to $1 \mathrm{~S} 1 \mathrm{~V}$ proposed here supports not only the selection of voice restrictions by the companies for which this is efficient ex-ante, but also the removal of these restrictions when they become inefficient ex post.

158. On the theoretical advantages of such sunset clauses, see L.A. Bebchuk, 'Why Firms Adopt Antitakeover Arrangements', 152 University of Pennsylvania Law Review 713 (2003). For an application to the takeover context, see Enriques and others, above n. 32, at 126.

159. Dallas and Barry, above n. 138, claim the temporary character of the disparity between classes of shareholders and argue, on this basis, that loyalty shares are intermediate between dual-class shares and $1 \mathrm{~S} 1 \mathrm{~V}$.

160. See Gilson and Gordon, above n. 16, at 910-11. 


\section{Conclusion}

In this article, I have discussed the policy responses to hedge funds activism in corporate governance. The analysis has been based on Hirschman's classic, Exit, Voice and Loyalty. Although Hirschman wrote before the re-concentration of ownership in the hands of institutional investors, which nurtured entrepreneurial activism by hedge funds, his framework can be adapted to the new situation. Contrary to the received wisdom, hedge funds do not pose problems of loyalty because the arbiters of their activism are typically quasi-indexers, which cannot exit strategically. What we can still learn from Hirschman, though, is that voice can be excessive for a particular company.

From this perspective, I have discussed hedge funds activism both empirically and in theory. This analysis reveals that, while the claim that the gains from hedge funds activism are short-lived is not borne out by the empirical evidence, the latter can tell us neither whether the existence of hedge funds activism leads to shorttermism in corporate governance nor whether this is efficient across the board. The real issue with activism is a conflict of entrepreneurship, namely a conflict between two views about the right time horizon for the target company to maximise uncertain profit - the view of the activist as opposed to the view of the incumbent management. Leaving the choice between these views to institutional investors is not efficient for every company 216 at every point in time.

In order to cope with this problem, this article has argued that regulation should refrain from curbing the power of activists. Rather, regulation should enable individual companies to limit the impact of activism when this is efficient for them. Reviewing the recent European experience with loyalty shares, this article contends that they operate as dual-class shares in disguise, sometimes allowing their midstream introduction without the approval by institutional investors. It is preferable for efficiency to allow dual-class recapitalisations explicitly, subject to a majority of minority vote conferring an effective veto power upon institutional investors. This 'sticky default' solution would screen the companies for which limiting the influence of activists is efficient, and induce these companies to negotiate timebound restrictions (for instance, sunset clauses) with institutional investors. 